\title{
HTR3A Gene
}

National Cancer Institute

\section{Source}

National Cancer Institute. HTR3A Gene. NCI Thesaurus. Code C25908.

This gene plays a role in neurotransmitter modulation and in chaperone activity. 